\title{
Sustainable Living and Co-Housing: Evidence from a Case Study of Eco-Villages
}

Marckmann, Bella Margrethe Mørch; Gram-Hanssen, Kirsten; Christensen, Toke Haunstrup

Published in:

Built Environment

DOI:

http://dx.doi.org/10.2148/benv.38.3.413

Publication date:

2012

Document version

Early version, also known as pre-print

Citation for published version (APA):

Marckmann, B. M. M., Gram-Hanssen, K., \& Christensen, T. H. (2012). Sustainable Living and Co-Housing:

Evidence from a Case Study of Eco-Villages. Built Environment, 38(3), 413-429.

https://doi.org/10.2148/benv.38.3.413 


\title{
Sustainable Living and Co-Housing: Evidence from a Case Study of Eco-Villages
}

\author{
BELLA MARCKMANN, KIRSTEN GRAM-HANSSEN and \\ TOKE HAUNSTRUP CHRISTENSEN
}

\begin{abstract}
In this article we examine aspects of the different arguments for the environmental advantages of co-housing compared with individual households. The analysis is structured around four main questions, which are argued to be decisive for the question of co-housing and sustainability. The first is whether co-housing offers better opportunities for choosing and using more sustainable technologies, which also relates to the question of whether co-housing offers better opportunities for building smaller and denser and thus more energy efficient buildings. The second and third questions are socially oriented; one relates to the claim that co-housing can support pro-environmental behaviour among residents as they can support each other's norms and practices. The fourth and last claim relates to a discussion of co-housing as a more sustainable opportunity especially for people living alone, as the growing number of small households is an emerging sustainability problem. The empirical analyses are based on the results from a Danish study of eco-villages including a survey, interviews with representatives of the eco-village movement and a detailed case study of a group of people in the process of establishing a new cluster in an existing eco-village. The aim of the article is to contribute to the general discussions about co-housing and sustainability. The study adds nuances to this discussion and shows that the answer is not as straightforward as presented in much of the literature.
\end{abstract}

The aim of this paper is to discuss to what extent and how co-housing can provide solutions to sustainable housing. The paper thus discusses the widely held view that co-housing can offer answers to a range of problems facing modern societies including alienation, social isolation and sustainable living (see, for instance, Abraham and deLaGrange, 2006; Assadourian, 2008; Lietaert, 2010; Maher and McIntosh, 2007; Meltzer, 2010; Torres-Antonini, 2006; Widener, 2010; Williams, 2005, 2007, 2008). Following the 1987 UN Brundtland Commission report Our Common Future, several authors emphasize that sustainability is not only a matter of environmental sustainability, but also of economic and social sustainability (e.g. Bergman et al., 2007; Crabtree, 2005; Maher and McIntosh, 2007; Williams, 2005). While recognizing the importance of all these aspects, in this paper we focus on environmental sustainability. Our aim is to inform the general discussions on co-housing and sustainability on the basis of a Danish case study of ecovillages.

Sustainable buildings and housing are contested terms including both grassrootsdriven holistic and context-based understand- 
ings as well as top-down and expert-based approaches (Jensen and Gram-Hanssen, 2008). This plurality covers a range of different concepts based on technological, social, aesthetic, commercial, and health issues (Guy and Farmer, 2001; Guy and Osborne, 2001; Guy and Moore, 2005; Dammann and Elle, 2006). Among these different approaches to sustainability issues within the housing sector there is, however, also agreement on many issues and goals, including, but not limited to, reduced energy consumption and renewable energy production (e.g. local energy production), lower resource consumption as well as recycling of materials and water.

In recent years, with climate change and $\mathrm{CO}_{2}$ emissions high on the political agenda, energy issues especially have been in focus in the field of sustainable housing. Housing does play a major role in mitigating climate change, since in most European countries approximately one-third of all energy is used directly in the housing sector with another third for transport (Eurostat, 2011). Reduction in energy consumption related to housing can be attained in different ways, including improved energy efficiency of buildings and appliances as well as better location of buildings in relation to transport. Research, however, documents that efficient technologies are only part of the answer to sustainability as the everyday routines of householders are as important as the physical and technical design (Gram-Hanssen, 2011).

In the following, we present first a brief review of the literature on co-housing and sustainability, including arguments about how co-housing can provide sustainable solutions as well as studies measuring the actual sustainability of co-housing. Next, the empirical material and methodology of the article are presented. In the analysis section, the empirical material is discussed in relation to four main arguments for sustainability within co-housing, and in the discussion and conclusion we summarize the problems and potentials of co-housing as sustainable housing.

\section{Arguments for Co-Housing and Sustainability}

When discussing the environmental sustainability of co-housing, it is important to focus on the influence of the technological structures as well as the routines and practices of everyday life. With regard to the technological structures, the literature on cohousing typically highlights two aspects in which co-housing can be expected to be more environmentally sustainable than other forms of housing, namely the adoption of more sustainable technologies and the reduction of floor space consumption. The first aspect relates to the assumption that the social organization of co-housing makes it more likely that environmentally friendly 'alternative' technologies will be employed. For instance, in an article in Cohousing - The Journal of the CoHousing Network published by the Cohousing Association of the United States, Coldham (1995) writes that the principal contribution of co-housing to a sustainable society is that it 'offers another scale of social organization - an intermediate scale between the single family and the town or municipality - thereby expanding the palette of technologies that can be applied' (here from Meltzer, 2005, p. 15). Similarly, Williams (2005) notes that high levels of social capital in co-housing can ease the implementing of environmental schemes (see also Meltzer, 2000).

The second argument for co-housing and sustainability related to technological structure is the assumption that co-housing communities are generally denser and take up less space in total per resident than other housing: 'Instead of spreading out houses, co-housing communities group homes together, enabling them to preserve more land as open space or farmland and to facilitate community connections by having neighbors within walking distance' (Assadourian, 2008, p. 154). Also, if built as terraced or semi-detached houses, energy consumption is reduced by minimizing heat loss from external walls. Graham 
Meltzer points out that these advantages can be realized more fully in co-housing communities than in ordinary single-family housing, since the social connections among residents enable them to tolerate a higher density (Meltzer, 2005). In addition to being closer together, the size of the individual dwelling is generally expected to be smaller than in other types of housing, because relatively rarely used functions such as guest rooms, hobby rooms and laundry rooms are shared (Williams, 2008). Reducing the heated floor space per person is important, as small houses in general consume less energy than large houses as well as taking up less land and requiring fewer resources in the building process (Meltzer, 2005; Wilson and Boehland, 2008).

With regard to routines and practices, the co-housing literature indicates that cohousing can be expected to be more environmentally sustainable because of the preference for sustainable everyday routines among residents. As mentioned earlier, technology alone does not guarantee sustainability. In the absence of sustainable practices, the energy savings gained by new technologies may simply be converted to increased consumption standards or more appliances (Gram-Hanssen, 2011). Does co-housing, then, support sustainable practices in daily life, once the houses are built and the technologies installed? Many authors think so: '... cohousing can be transformative by not only providing an eco-friendly physical setting, but also a social context in which pro-environmental attitudes are fostered and perpetuated', writes Torres-Antonini (2006, p. $40)$, and Williams $(2005,2008)$ points out that co-housing encourages pro-environmental behaviour in two ways. Firstly, the co-housing format (physical proximity and high levels of social capital) enables resource sharing in ways that are not so easily available to non-community residents. Examples include carpools, tool banks, organic gardening etc. Secondly, living in a community with strong pro-environmental norms reinforces the individual's commitment to sustainable practices such as garbage sorting, using less heat and hot water, using a clothesline instead of a tumble dryer etc. People not living in a community might in theory have similar routines, but several studies show that even though a large proportion of people intend to live a more sustainable everyday life, few realize their ideals in practice (Beattie and Sale, 2009; Munasinghe et al., 2009). Thus, the co-housing format, it is argued, may make a great difference by helping residents to follow their own ideals in practice.

Finally, and in addition to the more classical arguments for co-housing above, when discussing housing and sustainability, there is a question of household size, as it is documented that it is in general more energy and resource efficient to live more people together (Gram-Hanssen et al., 2009; Williams, 2007). As pointed out by Williams (2007), the relative sustainability advantage of moving into co-housing is bigger for smaller households, i.e. one- or two-person households, as these have in general a higher level of energy consumption per person compared with larger households. Hence, for co-housing to realize its full potential, it is necessary that this form of housing can be shown to be attractive to small households. This is even more important as the decline in household size and the increasing number of people living alone is a general trend found in most Western countries (Hall et al., 1997; Jamieson et al,, 2009). A recent study of Danish households documents that almost 40 per cent of all households in 2008 were occupied by only one person and that the number of one-person households is growing (Gram-Hanssen et al., 2009). It was also found that the growth in one-person households is particularly related to the group of people aged between 30 and 60 . Hence, the sustainability potential of co-housing will increase markedly if co-housing shows itself to be able to attract these households.

To sum up, the arguments that co-housing can play a vital role for the sustainability of 
future housing rests on four claims of the relative advantages of co-housing compared with other types of housing:

- more sustainable technologies built into houses;

- smaller and more compact houses;

- pro-environmental behaviour of residents;

- environmental advantages for one- and two-person households.

The above discussion points to a number of potential sustainability benefits of co-housing. However, relatively few studies have been made so far on the actual measurable environmental performance of co-housing (including eco-villages), and those that exist show ambiguous results. A Finnish study comparing eco-villages with conventional detached urban housing thus concludes that ecovillages have higher $\mathrm{CO}_{2}$ emissions when including construction, use and transportation in the analyses (Harmaajärvi, 2000). A Nordic study compared different types of eco-housing, some of which are co-housing, on selected indicators such as energy consumption, water consumption, waste production etc. The eco-houses were compared with each other and for some of the indicators also with similar data from average detached houses and apartment buildings. The study shows a quite varied picture (BechDanielsen et al., 1997). Some of the co-housing settlements in this study do show a better environmental performance on some of the indicators; however, the results are not unambiguously in favour of co-housing, especially not compared with average apartment buildings. In general, studies show that the realization of the sustainability potential of co-housing depends on a range of factors, not least location, since this to a large degree determines whether residents use cars or public transport. Rural communities are often heavily dependent on cars, except the few cases where most residents have managed to get work in the community or its vicinity.

Other important features are whether the buildings are purpose built for the community or are existing buildings that have been retrofitted (see for instance Harmaajärvi, 2000; Mulder et al., 2006; Williams, 2007). It could thus be argued that environmental evaluations should only compare co-housing with similar types of ordinary housing (e.g. rural co-housing with other rural housing and newly built co-housing with other newly built housing). An evaluation of a newly built Danish eco-village compares energy consumption with the energy requirements for new buildings according to the Danish Building Regulations (Foldager and DyckMadsen, 2002). The evaluation shows large variations between the individual households in the eco-village and that the ecovillage on average consumes more energy than stipulated in the Danish Building Regulations. This eco-village thus shows the same pattern as most other new Danish buildings, which also show big variations between families living in identical buildings and with new buildings having higher energy consumption than expected (Kristensen et al., 2010).

Thus, it is important to note that cohousing covers a wide range of different settlements, ranging from city/high-density cohousing, sometimes urban regeneration or brownfield developments, to eco-villages most often located in rural areas and new constructions. It is apparent that the potential for environmental sustainability varies widely between these types of settlements. In this article, we do not go further into the question of the environmental performance of cohousing and how to measure and quantify this. Instead, we discuss the four previous claims of co-housing's potential for more sustainable housing. Our aim is twofold: on one hand we would like to question the widespread assumption of co-housing being more sustainable than most other forms of housing, and on the other hand we would like to discuss how co-housing could be more sustainable and its potential role in relation to sustainable housing. 


\section{Methods and Data}

The discussion in this article is based on the empirical material from a $\mathrm{PhD}$ study on eco-villages in Denmark (Marckmann, 2009). This study includes a case study of a group of individuals working to establish a new residential cluster in an existing eco-village, a survey among 506 residents in eighteen Danish eco-villages, and four expert interviews with key persons related to the Danish eco-village movement. This article is not a summary of the PhD study or of its main conclusions, but rather a reuse of some of the empirical material related to the specific questions raised in this article.

Drawing on a study of Danish eco-villages in order to make more general conclusions about the potential of co-housing raises the question of how these eco-villages can be expected to differ from other co-housing communities. On one hand, eco-villages can be considered to be a subgroup of co-housing. Thus, most of the Danish eco-villages in this study fitted into the category of co-housing as defined by McCamant et al., (1993) in their study on Danish co-housing. This relates specifically to the following six criteria: (1) participatory processes; (2) neighbourhood design; (3) common facilities; (4) resident management; (5) non-hierarchical structure and decision-making; and finally (6) no shared community economy (see also Williams, 2005). Apart from two special cases (one without neighbourhood design and one with a strong shared-economy component), all eco-villages included in the survey qualify as co-housing communities according to these criteria.

On the other hand, eco-villages can in some respects also be considered a special subset of co-housing communities as they have a greater focus on sustainable living compared with other co-housing communities (Elm and Dilling-Hansen, 2003; Marckmann, 2009; Meltzer, 2010). This means that they are likely to attract people with a more explicit commitment to green living. In the context of this paper, eco-villages can thus be seen as a critical case because they can be expected to be more sustainable than other types of co-housing communities in regard to both the material structures (choice of sustainable technologies, smaller houses) and the routines and practices (encouraging pro-environmental behaviour). We use the term 'critical case' in the same way that Flyvbjerg (2006) does, meaning that if this case of co-housing does not provide evidence of sustainability, it is unlikely that other types of co-housing will do so.

The case study included participant observations of the group of persons planning to establish a new cluster of twelve households in an existing eco-village. The advantages of observing the group in the early stages included that the discussions and choices became visible, making it apparent that the final layout of the eco-village was not an inevitable or natural outcome, but rather the result of complex processes. The ecovillage studied was a relatively large community consisting at the time of study of five clusters, each home to about twenty adults and a number of children (both the ecovillage and the participants have been anonymized). In addition, two more clusters were in progress at the time of the study. The clusters included various forms of ownership: two were privately owned detached or semidetached houses, two were publicly rented terraced houses and one was a cooperative (also terraced houses). The prospective residents of one of the new clusters, Cluster 7 , decided to work with a design built around twelve privately owned detached houses. During the observation period, the group consisted of twenty-two adults: seven twoparent families with one or more children at home, one single-parent family with one child, three couples with no children and one single male. The group met monthly in order to decide a wide range of issues in preparation for the actual construction work. Meetings were followed during 9 months. The researcher was present at all meetings, 
but did not participate in the discussions. The meetings were recorded on video for later transcription.

In this paper, the data from the observations are mainly used to show how sustainability is negotiated in the group and in this connection to discuss the first two sustainability claims: choice of sustainable technologies and smaller housing size.
The main reason for this is that the size of the dwellings and the choice of sustainable technologies are to, a large extent, determined in the initial discussions of the establishment phase of a new community (like Cluster 7).

The survey of residents in Danish ecovillages is mainly used in the discussion of the third and fourth claims, i.e. whether co-housing encourages pro-environmental
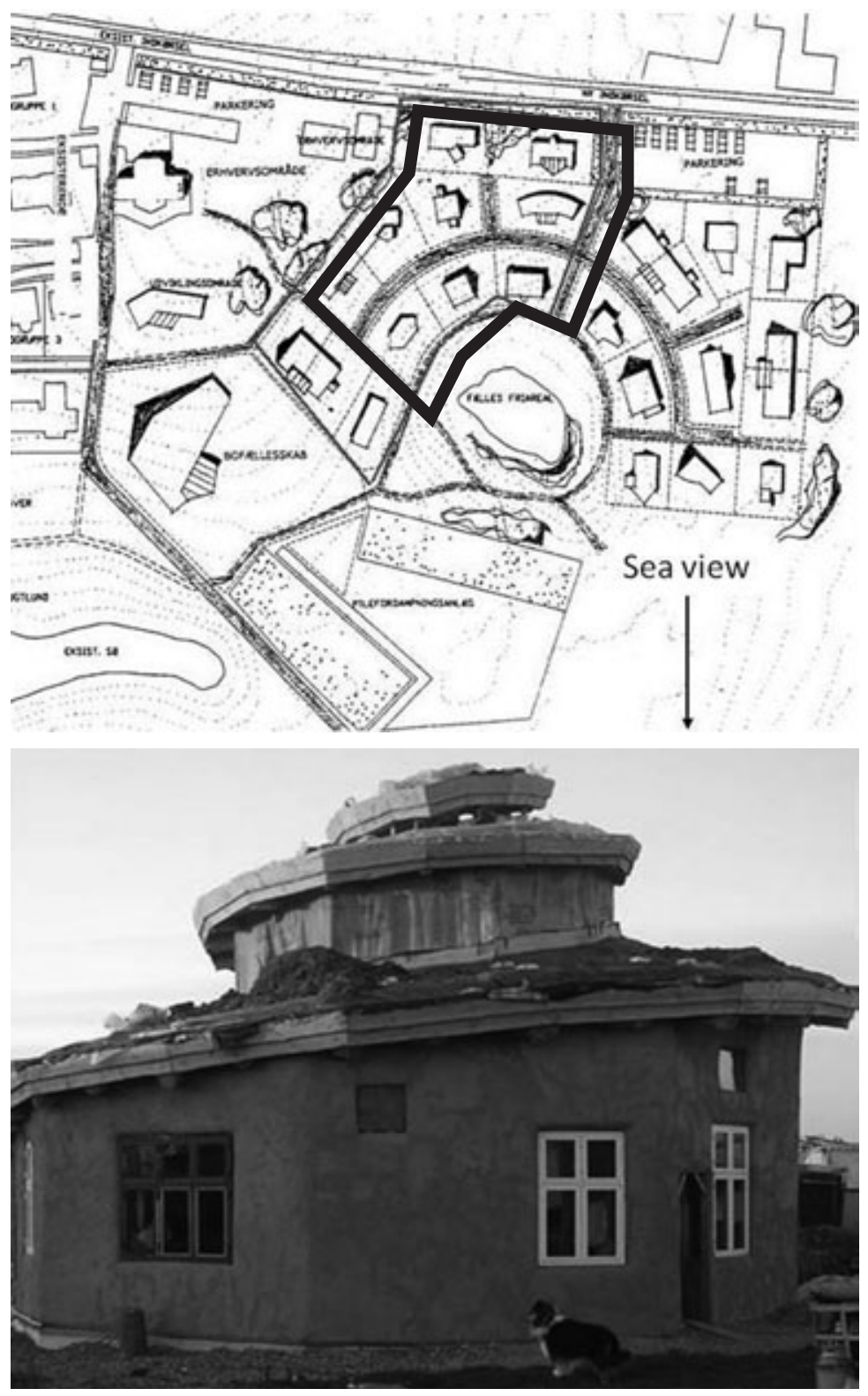

418
Figure 1. Map of the east end of the eco-village. The area outlined is the projected new cluster.

Figure 2: The 'Conch House' in the ecovillage Fri \& Fro, Denmark. (Photo courtesy of: www.klimabyggeri.dk)

BUILT ENVIRONMENT VOL 38 NO 3 
behaviour and whether co-housing attracts one- and two-person households. As mentioned above, the survey was not designed to throw light on the sustainability of the eco-villages, since the main focus was the social relations in the eco-villages. However, some respondents did bring up the topic of sustainable practices in their answers to open questions about the main advantages and disadvantages of living in eco-villages. For this reason, the survey data in this article is only used to establish the socio-economic composition of the population (below), and as a source of statements about the importance of community living for mutual support of sustainable practices.

The survey shows a predominance of welleducated, middle-class, ethnic Danes in the eco-villages (Marckmann, 2009). This is unsurprising in the light of comparable data from other countries. For instance, Graham Meltzer (2005) finds that co-housing residents in North America are predominantly white, middleclass, well-educated professionals, 80 per cent of whom have a college degree compared with 30 per cent in the population (see also Williams, 2005). A similar trend is found in the Danish eco-villages with 72 per cent having 4 years or more of tertiary education compared with 23 per cent of Danes in general (Marckmann, 2009). The members of Cluster 7 were no exception to this rule.

\section{Sustainability Advantages of Co-Housing}

In the following, we examine the four main arguments for co-housing being more sustainable than ordinary housing: that co-housing communities are more able and willing to implement sustainable technologies; that cohousing communities enable residents to accept less individual living space; that the social structure of co-housing facilitates sustainable everyday practices of the residents; and finally, that co-housing can be a solution to the environmental challenges of smaller households by attracting one- and two-person households.

\section{Sustainable Technologies}

In those communities inspired by the ideas behind the eco-village movement, a lot of focus has been on selecting and using sustainable and sometimes experimental technologies such as solar heating, solar power, Finnish mass ovens, alternative wastewater technologies etc. (Marckmann, 2009). Compared with other co-housing communities, ecovillages attract more people interested in building their own houses and working with experimental technology solutions such as composting toilets. Since the decisions about which technologies to opt for have to be made early in the construction process, it is understandable that they are given a lot of attention by prospective co-housing residents (like in Cluster 7). However, what does it mean for a technology to be considered 'sustainable'? The following examples from the meetings in Cluster 7 show the importance related to the choice of technologies by a group of prospective ecovillagers as well as the difficulties they faced in negotiating criteria for sustainability.

According to the bylaws of the eco-village, all houses had to be equipped with solar panels for hot water supply, but for the winter months a source of supplementary heating was needed. The existing eco-village had established a collective central heating known as the 'Energy Central' supplying a number of housing units with district heating from locally sourced wood chips. The members of Cluster 7 had several options open to them: they could choose to join the Energy Central collectively; some houses could join while others could establish individual solutions; all could establish individual solutions; or they could establish a new collective solution of their own. The group agreed that irrespective of the source of the heat, all houses needed to conform to certain energy standards, meaning that they would need a relatively small amount of energy for heating.

The topic of heating technologies was discussed at length at four consecutive meetings. 
At these meetings, the topic took up 30-90 minutes of a typical three-hour meeting. No final decision was reached before the end of the observation period. The first important question raised was one of individual versus collective solutions:

David: The principle under discussion here is whether one wants an individual or a collective heating supply. I can only say, we have the heating in [Eco-village], supposedly built after the rules, and we have about 30 per cent heating lost in the ground, in the pipes, so that 30 per cent of the heating we pay for is used to keep the ground warm. And I think this is an argument against drawing the pipes an even greater distance... We have to heat the pipes in the ground, but since the pipes are less well-insulated than the houses, the water loses heat while in the pipes, in the ground. (45 year old male, biologist, single, one child)

Claus: This guy, you know who he is, he edits this journal of bioenergy ... he didn't believe it... He didn't believe that we could do better by going individual ... he said that the small furnaces pollute more than the big furnaces. That's what he said. (45 year old male, joiner, in a relationship, no children)

David: Another thing, I think that [Eco-village] is a place where we ought to have room for experiments, people should be allowed to experiment... I really think it would be a pity, instead of joining the public monopoly we just turn our own Energy Central into a monopoly, force people to join that... I don't like those central solutions. I don't like to be tied up to people's expectations about cost, and then it turns out to be more expensive after all... I want to try something like passive solar heating and maybe biogas, maybe a stoker, I want to experiment with my energy... I don't think I learn anything from just turning on a tap in the utility room. I think it would be more fun to create an individual heating source.

Lars: What is our motivation, is it the economic or the environment that counts here? I don't have the answer... OK, we have some heat loss, but Allan [responsible for Energy Central] showed me this huge book written by [a firm of consulting engineers] showing that individual furnaces emit a whole lot more carbon... So how do we weigh these things against each other?... Another thing is, what do we want, do we need to make room to deliver coal or have individual heating oil containers, and trucks coming up to every house with wood chips? It's a choice we have to make. (45 year old male, organic farmer, married, 4 children)

David: People should be aware that if we join the Energy Central then we also join the 24 hour rotation, so the alarm might ring in the middle of the night if the burner stops working. It's a lot of work to keep that going.

As the discussion progressed, more and more criteria were made relevant to the choice of heating source: efficiency, emissions, convenience, fun, consequences for the design and day-to-day use of the area (providing for individual delivery and storage of fuel could have design implications as well as compromise the principle of no vehicles beyond the parking lot). Everybody agreed that all solutions, whether individual or collective, must be justifiable from a sustainability perspective. However, the definition of sustainability proved elusive:

Olga: It is important to get it out in the open if some people don't think we're being ambitious enough. (35 year old female, educator, married, no children)

Hans: When I think sustainable, I'm mainly worried about the electricity-based solutions like heat pumps of various kinds... Do we accept those kinds of solutions? That's a principle at stake. (40 year old male, engineer, married, one child)

Claus: Well, a few years ago heat pumps were banned because they use a lot of electricity, which is based on coal, and it still is, but I think it can be discussed. Now we have a lot of wind turbines, and that's a different perspective. On the other hand, wood stoves emit a whole lot of particles if it is not used in the right way. (45 year old male, joiner, in a relationship, no children)

Svend: I thought wood was carbon neutral? (35 year old male, teacher, married, one child)

Claus: That's a different issue, there's the question of carbon, wood is carbon neutral, all biofuel is, but it's a question of particle emissions...

David: We're comparing apples and pears and oranges here. (45 year old male, biologist, single, one child)

BUILT ENVIRONMENT VOL 38 NO 3 
Although the group did not succeed in making a final decision during the observation period, it did not mean that nothing was achieved. Maybe most importantly, the group made advances towards a working definition of sustainability. Sustainability turned out to be not a self-evident quality, but open to negotiation (cf. Godard, 2007). In this context, it was mainly connected with efficiency, carbon emissions and particle emissions, but also connected with aspects of aesthetics and social relations and landscape planning. The group did not (and probably could not) establish a final, positive definition of sustainability, but did establish a series of negative definitions: sustainable technologies must be carbon neutral, must not pollute, must not be wasteful etc.

\section{Small and Compact Houses}

The high density and high space efficiency of co-housing communities are perhaps their most important advantage in relation to environmental sustainability. However, these are also qualities that are not easily compatible with widespread cultural ideals of large dwelling spaces. The following excerpts from the meetings in Cluster 7 show that even in a group committed to the ideal of sustainable living it can be hard to challenge others' ideas of the 'dream house'. Prior to the observation period, the members of Cluster 7 had already decided that they wanted to build individual, single detached houses, i.e. not terraced or semi-detached houses.

Minna: Would anybody consider building semidetached houses? (30 year old female, PRconsultant, in a relationship, two children)

(silence)

David: Well, that's what Cluster 1 did. The advantage of semi-detached houses is that the outside area seems bigger, and you save a bit on the heating. (45 year old male, biologist, single, one child)

Birgit: The way I read the group right now, that's not where people are. (45 year old female, landscape architect, married, no children)
Claus: It is good to just get the thought on the table, there's some economy in semi-detached houses too. (45 year old male, joiner, in a relationship, no children)

Nothing more was said about semidetached or other compact housing types during the observation period. The environmental consequences of house size were not mentioned at all. This was remarkable, since discussions such as the one about heating sources showed that the members of the group were well able to challenge each other on grounds of sustainability in other contexts. The following is an excerpt from the meeting where each family presented their ideas about their future home. The sizes of the floor space mentioned can be compared with the average size of Danish single-family houses of that period, which were $140 \mathrm{~m}^{2}$ for all houses and $155 \mathrm{~m}^{2}$ for new houses.

First those wanting small houses:

Birgit: The project we're working on is $80-90 \mathrm{~m}^{2}$, because we don't want to build big, also so we don't block the view for those in the back row. (45 year old female, landscape architect, married, no children)

Olga: We want a tiny house of $75-80 \mathrm{~m}^{2} \ldots$ and it will be really simple with a living room/kitchen, bedroom, bathroom and hallway, that's really functional from what we have found out over the years, really simple. That's how we like it, so we're not compromising in any way, that's just how we like it. (35 year old female, educator, married, no children)

Anders: I'll start out with a prefab office pavilion here and then I'll begin building my house, about $40 \mathrm{~m}^{2}$ to begin with. I want to build it myself and then add to it along the way, when I need it, instead of saddling myself with huge expenses from the start. (45 year old male, musician, single)

The reasons given for building small houses vary from consideration for others over personal taste to economic considerations. However, the sustainability theme is not mentioned. Nor is it mentioned by any of the families wanting large houses:

Else: Apart from that, we need to have room for our three kids, so we're thinking of a house about 
$140 \mathrm{~m}^{2}$. (50 year old female, nurse, married, three children)

Tine: We are up there too with 3-4 kids, so we want to build $170 \mathrm{~m}^{2}, 180 \mathrm{~m}^{2}$, and in two storeys... (30 year old female, teacher, married, two children)

Niels: We want two storeys and there are four of us, so we are above $150 \mathrm{~m}^{2}$. (30 year old male, married, two children)

Hans: We plan on having more kids, and I need to be able to work from home, so we need some room, so we're talking about $180 \mathrm{~m}^{2}$ in two storeys... (40 year old male, engineer, married, one child)

David: But why do you need a workspace at home when we are going to build shared office space right next door? (45 year old male, biologist, single, one child)

Birgit: He has to mind all those kids. (laughter) (45 year old female, landscape architect, married, no children)

The desire for large houses was justified with reference to the number of people in the household. This was not challenged, even though everybody in the group knew that only the youngest of Else's three sons still lived at home, that Tine so far had only two children, and that Hans and his wife so far had only one child. David's attempted challenge of Hans's declared need for office space was interrupted and not resumed within the observation period. This was remarkable since the space requirements of these families were actually forcing the group to admit only eleven families instead of twelve as originally planned (according to the local planning regulations the built area may only cover 35 per cent of the total lot) which consequently made the economic and practical burden on the remaining families greater.

Later during the observation period, the group spent a lot of time discussing whether or not to build a common house in the beginning of the design phase or later. Again, nobody connected this discussion to the issue of sustainability by saying that a good common house would reduce the need for private spaces. The sustainability aspect, so prominent in the discussion of heating solutions, was conspicuously absent when it came to the size of the houses.

\section{Mutual Support of Sustainable Practices}

Even though the discussion about the material structures took up most of the attention in the early phases, in the long run the daily practices of residents are at least of equal importance in determining the relative sustainability of co-housing. This topic was only sporadically touched upon in the discussion in Cluster 7, and mainly in the indirect form of comments indicating that some members, at least, were aware that both technology and user practices are important:

Claus: there are results that show that together with traffic, it is the individual emissions from wood stove that are comparable [to traffic] polluters, because people just put up an iron stove and burn all kinds of rubbish, and they don't control it, and most of it just goes right out there. And it really demands that you choose some good stoves and have a decent culture, and that can't be controlled centrally, if that's the way we choose to go. (45 year old, joiner, married, no children)

What Claus was saying was that the daily user context of a technology should be taken into account when choosing between technologies. However, the group did not at any point during the observation period address the question of sustainable practices as opposed to sustainable technologies.

In the eco-village survey, residents of existing eco-villages were asked to describe the advantages and disadvantages of living in an eco-village in their own words. The following answers were typical and indicated that some residents acknowledged the importance of social support in realizing the ideal of sustainability and 'green living':

'The fact that we can do a lot more together than each could do on his own.' 
'To be able to emphasize sustainability and the organic way of life and to reinforce each other in the importance of that commitment.'

'The opportunity to live in a reasonably sustainable way.'

'The organic way of life, that material goods are not top priority, the fact that we live surrounded by nature, that we have animals, living with others whose attitude to life is the same as mine.'

In one of the eco-villages studied, prospective residents or interested members of the public could download a fact sheet stating, among other things, that:

Wastewater is separated in urine and other waste. For that reason it is important to pee only in the front part of the separation toilet. In order to keep the sand filter working there are restrictions as to what should be flushed down the toilet or the drain.

This community chose alternative technologies (separation toilets, sand filters etc.) that demand certain practices from users in order to work properly and to fulfil the promise of sustainability. The technologies provide the community with a legitimate reason to control even very intimate habits of the residents. In a similar way, the existence of shared facilities such as freezers, laundries and kitchens give the residents occasion to discuss these matters:

The group discussed the question of residents buying freezers and placing them in the common storage area. Some felt that freezers are a private luxury which residents ought to find room for in their own houses, while others argued that freezers located in the common area are more likely to be shared, thus saving energy and freezer space in the long run. (Observation notes from a meeting in an existing eco-village)

Our data thus partly support the claim that co-housing, to some degree, furthers sustainable routines and practices among residents. Again, one of the most important effects can be that it becomes legitimate in the communities to discuss everyday practices and potentially challenge and inspire each other to more sustainable behaviour.

\section{Including Small Households}

As mentioned previously, the demographic transition towards smaller households is an important driver of increasing energy consumption. Thus, co-housing could be a more sustainable choice of housing for small households. This leads to the question to the extent to which co-housing communities are attractive to one- and two-person households, and to what extent the communities are able to include these.

Based on the survey, table 1 shows that 42 per cent of the adult residents in the eco-villages lived with spouse and children and 9 per cent lived alone with children. Thus, families with children were overrepresented in the eco-villages compared with the Danish population in general, where the equivalent figures were 27 per cent and 4 per cent, respectively. One- and two-

Table 1. Household composition in eco-villages (Marckmann, 2009). Figures for Denmark based on Statistics Denmark (2011) Table FAM122N (www.dst.dk).

\begin{tabular}{|c|c|c|c|}
\hline & Number & $\%$ & $\begin{array}{l}\% \\
\text { in Denmark }\end{array}$ \\
\hline I live alone & 101 & 20.7 & 24 \\
\hline I live with spouse/partner without children & 107 & 21.9 & 33 \\
\hline I live alone with one or more children & 42 & 8.6 & 4 \\
\hline I live with spouse/partner and one or more children & 207 & 42.3 & 27 \\
\hline I live with others & 32 & 6.5 & 12 \\
\hline Total & 489 & 100 & 100 \\
\hline
\end{tabular}


person households, conversely, were underrepresented in eco-villages with 21 per cent of adults living alone and 22 per cent living with spouse and no children (the national figures were 24 per cent and 33 per cent, respectively).

Apparently, the eco-villages are not attracting many one-person and, especially, two-adult households, but do, on the other hand, appear to attract more than their share of single parents. There can be at least three possible explanations of this.

The first concerns the age of the communities. Most of the eco-villages studied here were comparatively new. The oldest communities were founded in the 1970s, the newest were still taking shape at the time of study. Given that new communities attract many families with young children, these families will naturally be over-represented in the first generation of the communities' existence, but eventually a demographic transition will take place and the composition will come to resemble the one prevalent in the general population. When the children grow up and move away, presumably the parents will stay in the communities, now as one- or twoperson households.

The second reason can be that the ecovillages are not attractive to the small households. Those same qualities which attract families with young children may do the opposite for singles and childless couples, who enjoy an easier mobility. Often located in suburban or rural areas, eco-villages do not offer as varied a range of cultural activities or opportunities for meeting new people as can be found in the city centres. Recent research on housing preferences shows that young singles predominantly want to live close to the city centres (Kristensen and Andersen, 2009). Also, the community activities such as common meals may be seen as too childdominated.

The third explanation can be that communities tend to exclude small households. A recent study of one-person households in Denmark (Gram-Hanssen et al., 2009) shows that this group has a significantly lower level of income and education compared with people living with others. Among adults between 30 and 60 years old, 30 per cent of those living alone are not employed compared with 12 per cent for other household types, and 18 per cent of those living alone are on early retirement compared with 5 per cent among other households types. Co-housing communities, on the other hand, are mainly populated by residents with a high socio-economic status (i.e. well-educated, reasonable income and a high level of employment within especially public-sector jobs). Thus, a considerable proportion of those living in one-person households may lack the economic or social resources needed to fit in and be accepted into a co-housing community (cf. Bouma and Voorbij, n.d.; Williams, 2008).

Based on the available data, it is not possible to conclude which of these explanations is most plausible - or whether, perhaps, the answer is a combination of them all. Nevertheless, it is important to note that small households are not a homogenous group. Some are young while others are old, and some are well off while others have a low income. Therefore, if co-housing is pursued as a strategy targeted at one- and twoperson households, it is important to take into account the variation within this group related to age and social status. Thus, the environmental benefits related to a widow or widower who moves from a detached house and into a co-housing community with terraced or semi-detached houses are in general much greater compared with a young adult moving from a two-room flat in a block of flats. Also, the different groups of one- and two-person households may ask for different kinds of communities with different kinds of location (e.g. urban versus rural), social organization (e.g. hierarchical versus egalitarian), ideals for the balance between the private and the communal etc. 


\section{Discussion}

This section summarizes the findings from our study of Danish eco-villages with regard to the four potential environmental advantages of co-housing. The main analytical question is whether our study supports the general assumption that the organizing form of co-housing enables a more sustainable way of housing and living?

With regard to sustainable technologies, the social organization certainly enables (and forces) residents to be actively involved in decisions regarding the technologies built into their homes. However, the case study suggests, at least in the case of communities building their own homes rather than retrofitting existing buildings, that there is a risk that the discussions of alternative solutions might take up an amount of energy and time out of proportion with the actual advantages of choosing the best technology, especially as the degree of energy efficiency (e.g. insulation) of the houses and the daily routines of the residents might in the end be more important for the total energy consumption of the community. The question might be raised as to whether the group in this case study could have saved themselves time and trouble by getting expert help. Communities subscribing to a specific set of principles, such as Permaculture, might indeed have an easier time making such decisions. This group, which did not have any such prior collective agreement, did in fact at one point decide to call in an expert, but this only led to renewed discussions of which expert would be the right one, what type of expertise was needed, etc. However, as our case study concerned eco-villagers establishing themselves in a new settlement, it is likely that this type of discussion would be less dominant in other types of co-housing (e.g. co-housing in existing buildings in urban areas).

As for the assumption that co-housing residents live in smaller and denser houses, our study illustrates that this is not necessarily a corollary of the co-housing format. The explanations for the particular way this question was handled (or not handled) in this case study may include group dynamics. The families wanting big houses were among the most active group members, and challenging their desires might potentially cause tensions in the group. Also, the idea that more space is always desirable is a strong cultural ideal. The discussion of housing size has also to be seen in the context of how individual families live their life. In Denmark, it is common for grown-up children to keep 'their' room in their parents' house for years, even though they only use it for occasional stays and for storage of old items. Thus, challenging the couple with two grown-up sons on the size of their house would mean that they would have to tell their sons to book a guest room in the common house when they came home to visit them. This shows that the choice of joining a co-housing community or, in this case, an eco-village does not necessarily indicate an alternative set of values to the 'social mainstream'; or, in other words, a commitment to sustainability does not exclude attachment to individualism, common expectations of living standards, etc.

Unfortunately, data on the exact sizes of houses in Danish co-housing communities and eco-villages are not available. However, earlier studies suggested that Danish cohousing communities are typically built as semi-detached/terraced one- or two-storey houses (McCamant et al., 1993). Detached houses as well as blocks of flats appear to be relatively uncommon among Danish co-housing communities in general. Therefore, it seems that on average Danish cohousing is smaller and denser compared with detached houses, but less compact than blocks of flats.

Similarly, the question of the environmental aspects of everyday practices was also not discussed by the group of prospective ecovillagers during the observation period. The quote about wood stoves indicates that controlling individuals' behaviour was not 
seen as being within the group's power. However, the quotes from the survey of established communities indicate that it is possible to challenge each other's behaviour from a sustainability angle, and thus make it easier to realize pro-environmental behaviour in a community setting. On the other hand, it must be kept in mind that the residents of eco-villages and other co-housing communities are self-selected by what is probably the most sustainability-aware segment of the population. And while these individuals may find support for their behaviour by living in a community with like-minded persons, this concentration of committed individuals potentially means that they are not making their influence felt in other contexts such as residents' associations, local politics etc.

With regard to attracting small households, our study shows that couples without children and people living alone are underrepresented in these settlements. Whether this is because the eco-villages (unintended) exclude these people or whether eco-villages are not attractive to them is difficult to determine. Nevertheless, it can be concluded that this specific type of co-housing does not provide an answer to the environmental challenges of declining household size. Again, there are presumably important differences between different types of co-housing, as co-housing in urban areas (and particularly in larger cities) is probably more attractive to these types of households than rural and suburban eco-villages.

Table 2 summarizes the four sustainability claims of co-housing and our main findings from this study.

On a more general level, the study shows that eco-villagers fail to bring the general increase in consumption through increasing standards of comfort and convenience into their discussions. The consumption growth gradually outweighs the gains from increasing energy efficiency, which is the main reason why the Danish residential energy consumption has been constant (and not been falling) during the last three decades (Christensen et al., 2007; Røpke, 1998). The failure to bring the general growth in consumption into focus was most evident in relation to the prospective eco-villagers' discussion of the floor space of their future homes; as already pointed out, the ecovillagers in many ways reproduced the same ideas and aspirations for large space as is representative for most other homeowners. And even though the size of the homes might in the end prove more decisive for the final carbon footprint of the community than the choice of heating system, these ideas and aspirations are not challenged by the eco-villagers. It is remarkable that these

Table 2: Summary of the four sustainability claims and main findings from this study.

\begin{tabular}{ll}
\hline Sustainability Claim & Findings of this Study \\
\hline $\begin{array}{l}\text { More sustainable technologies } \\
\text { built into houses }\end{array}$ & $\begin{array}{l}\text { Cohousing format furthers active involvement with technology. } \\
\text { Risk that choice of technologies takes up disproportionate amount } \\
\text { of time/energy }\end{array}$ \\
$\begin{array}{l}\text { Smaller and more compact houses } \\
\text { Strong cultural ideals working against small/compact houses. } \\
\text { Explicit focus on the importance of housing size from beginning } \\
\text { of the design process is needed to counter this. }\end{array}$ \\
$\begin{array}{l}\text { Co-housing format seems to challenge and inspire individuals' } \\
\text { everyday practices }\end{array}$ & $\begin{array}{l}\text { So far, dedicated, self-selected individuals dominate in cohousing } \\
\text { - uncertain how it would work in broader population. }\end{array}$ \\
& $\begin{array}{l}\text { So far, one- and two-person households without children are } \\
\text { under-represented in eco-villages. }\end{array}$ \\
\hline $\begin{array}{l}\text { Environmental advantages } \\
\text { for one- and two-person households }\end{array}$
\end{tabular}


prospective eco-villagers, who are supposed to be particularly interested in environmental issues, did not succeed in addressing the underlying growth in resource consumption in their design of their future eco-village community.

\section{Conclusion}

Co-housing is often seen as a sustainable alternative to traditional housing. However, the analysis in this article adds nuances to this and shows that the answer is not as straightforward as presented in much of the literature. On the basis of a study of eco-villages in Denmark, we have discussed four key questions related to the supposed sustainability benefits of co-housing. In the following we will summarize what can be learned from this case study.

The choice of more sustainable technologies appears to be the most important and direct advantage of co-housing. Thus, our case study supports previous findings that co-housing communities are more motivated to and capable of installing and experimenting with technologies like solar power or composting toilets. The social organization of the cohousing community creates a shared space for detailed discussions about technologyrelated questions. However, our case study also indicates a tendency to focus more on new and visible sustainable technologies rather than more inconspicuous solutions like thermal insulation. Thus, there seems to be blind spots with regard to the discussion of technology and sustainability.

While the eco-villagers succeed in addressing the question of sustainable technologies, it is less evident that co-housing provides better opportunities for smaller and denser housing. Our case study shows that this is certainly not a simple outcome of the co-housing format and that it is highly influenced by the general cultural norms and ideals of large living space. Also, the environmental aspects of this are not a main issue in the discussions of prospective eco-villagers.
Having this in mind, other evidence indicates that Danish co-housing communities are in general smaller and denser compared with detached housing in rural and suburban areas. Thus, it is likely that co-housing is more energy efficient than typical detached single-family houses, but less efficient than traditional blocks of flats where most flats share walls with two or three other flats. Thus, the relative environmental advantage of co-housing regarding living space and building density is limited.

Also with regard to whether co-housing can help people support each other in achieving more sustainable daily routines, the results of our study are equivocal. While the case study of prospective eco-villagers shows that the question of pro-environmental daily practices was almost completely absent from group discussions, the survey results partly support the assumption that pro-environmental routines are part of the discussions in established co-housing communities (e.g. in relation to use of alternative technologies such as composting toilets). Thus, co-housing appears to create a space for discussion and mutual support and control of individual residents' daily behaviour and routines.

While co-housing supports the choice of more sustainable technologies and to a limited degree also more sustainable everyday practices and smaller and denser buildings, our findings do not indicate that co-housing is successful in attracting small households. Therefore, co-housing does not (yet) seem to play a role in mitigating the threat to sustainability from the demographic trends towards smaller households. Our study highlights the importance of distinguishing between various types of small household. For single parents, the ecovillages may be attractive, but they may lack the social and economic resources required to live there. For others, such as young singles or couples, the eco-villages may be located too far from city centres to be attractive. These differences should be taken into account in possible future policies focusing 
on tackling the environmental challenge from smaller households by, for example, motivating one and two-person households to move into co-housing.

Finally, co-housing does not succeed in addressing the general growth in consumption, which has historically been the main reason why it has not yet been possible to realize significant reductions in residential resource use. Thus, co-housing does not seem to hold the 'critical potential' for more profound changes in consumption practices and lifestyle that could potentially challenge modern consumer culture. Nevertheless, as noted above, co-housing does have some environmental advantages, which is to a large degree enabled through the social organization of co-housing. The social organization might actually be the most important strength of co-housing and could in the long run play a vital role as the foundation for more profound and collectivebased changes in consumption and everyday practices in a possible future scenario with resource scarcity and soaring energy prices.

\section{REFERENCES}

Abraham, N. and deLaGrange, K. (2006) Elder cohousing - an idea whose time has come? Communities, 132, pp. 60-69.

Assadourian, E. (2008) Engaging communities for a sustainable world, in Starke, L. (ed.) State of the World 2008: Innovations for a Sustainable Economy. New York: W.W. Norton.

Beattie G. and Sale, L. (2009) Explicit and implicit attitudes to low and high carbon footprint products. International Journal of Environmental, Cultural, Economic and Social Sustainability, 5, pp. 191-206.

Bech-Danielsen, C., Hansen, J.S., Jensen O.M. (1997) Økologisk byggeri $i$ de Nordiske lande. Copenhagen: Nordisk Ministerråd.

Bergman, N., Whitmarsh, L., Köhler, J., Haxeltine, A. and Schilperoord, M. (2007) Assessing transitions to sustainable housing and communities in the UK, in Horner, M., Hardcastle, C., Price, A. and Bebbington, J. (eds.) International Conference on Whole Life Urban Sustainability and its Assessment. Glasgow: Glasgow Caledonian University.
Bouma, J. and Voorbij, L. (n.d.) Factors in Social Interaction in Cohousing Communities. Available at: http://www.utwente.academia.edu/Jantine Bouma.

Christensen, T.H., Godskesen, M., Gram-Hanssen, K., Quitzau, M.-B. and Røpke, I. (2007) Greening the Danes? Experience with consumption and environment policies. Journal of Consumer Policy, 30, pp. 91-116.

Coldham, B. (1995) The CoHousing path to sustainability. CoHousing: Journal of the CoHousing Network, 8, pp. 19-21.

Crabtree, L. (2005) Sustainable housing development in urban Australia: exploring obstacles to and opportunities for ecocity efforts. Australian Geographer, 36, pp. 333-350.

Dammann, S. and Elle, M. (2006) Environmental indicators: establishing a common language for green building. Building Research \& Information, 34, pp. 387-404.

Elm, A. and Dilling-Hansen, T. (eds.) (2003) Økosamfund i Danmark. Hvordan drømme bliver til virkelighed. Galten, Denmark: Landsforeningen for Økosamfund.

Eurostat (2011) Final Energy Consumption, by Sector. Indicators - Sustainable Consumption and Production. Available at http://www.epp.euro stat.ec.europa.eu/portal/page/portal/sdi/ indicators/theme2. Accessed 20 July 2011.

Flyvbjerg, B. (2006) Five misunderstandings about case-study research. Qualitative Inquiry, 12, pp. 219-245.

Foldager, I. and Dyck-Madsen, S. (2002) Munksøgård - Erfaringer og anbefalinger. Copenhagen: Det Økologiske Råd.

Godard, O. (2007) Is sustainable development an alternative principle of justification? in Thoyer, S. and Martimort-Asso, B. (eds.) Participation for Sustainability in Trade. Aldershot: Ashgate.

Gram-Hanssen, K. (2011) Households' Energy Use - Which is the More Important: Efficient Technologies or User Practices? Paper presented to the World Renewable Energy Conference, Linköping.

Gram-Hanssen, K., Scherg, R.H. and Christensen, R.S. (2009) One-Person Households - A Growing Challenge for Sustainability and Housing Policy. Paper presented to the European Housing Research Network Conference, Prague.

Guy, S. and Farmer, G. (2001) Reinterpreting sustainable Architecture: the place of technology. Journal of Architectural Education 54, pp. 140-148. 
Guy, S. and Moore, S.A. (eds.) (2005) Sustainable Architectures. Cultures and Natures in Europe and North America. London: Spon Press.

Guy, S. and Osborne, S. (2001) Contesting environmental design: the hybrid green building, in Guy, S., Marvin, S. and Moss, T. (eds.) Urban Infrastructure in Transition: Networks, Buildings, Plans. London: Earthscan.

Hall, R., Ogden, P.E. and Hill, C. (1997) The pattern and structure of one-person households in England and Wales and France. International Journal of Population Geography, 3, pp. 161-181.

Harmaajärvi, I. (2000) EcoBalance model for assessing sustainability in residential areas and relevant case studies in Finland. Environmental Impact Assessment Review, 20, pp. 273-380.

Jamieson, L., Wasoff, F. and Simpson, R. (2009) Sololiving, demographic and family change: the need to know more about men. Sociological Research Online, 14.

Jensen, J.O. and Gram-Hanssen, K. (2008) Ecological modernization of sustainable buildings: a Danish perspective. Building Research and Information, 36, pp. 146-158.

Kristensen, H. and Andersen, H.S. (2009) Befolkningens boligønsker. Copenhagen: Center for Bolig og Velfærd, Realdania Forskning.

Kristensen, L., Jensen, O.M., Knudsen, H.N., Rasmussen, T.V., Bergsøe, N. C., Kragh, J., Arvedsen, H. and Olsen, T. (2010) Erfaringsopfølgning på lavenergibyggeri klasse 1 og 2: Med 'Fremtidens Parcelhuse' som eksempel. Køge, Denmark: Det Grønne Hus.

Lietaert, M. (2010) Cohousing's relevance to degrowth theories. Journal of Cleaner Production 18, pp. 576-580.

Maher, S. and McIntosh, J. (2007) A Shared Sense of Belonging: The Politics of Defining in Sustainable Community Housing Typologies. Paper Presented to the 2nd International Conference on Sustainability Engineering and Science, Auckland.

Marckmann, Bella (2009) Hverdagslivets kritik: Økosamfund i Danmark. PhD thesis, Sociologisk Institut, Copenhagen.

McCamant, K., Durrett, C. and Hertzman, E. (1993) Cohousing: A Contemporary Approach to Housing Ourselves, 2nd ed. Berkeley, CA: Ten Speed Press.

Meltzer, G. (2000) Cohousing: towards social and environmental sustainability, unpublished PhD thesis, Department of Architecture, University of Queensland, Brisbane.
Meltzer, G. (2005) Sustainable Community: Learning from the Co-housing Model. Victoria, BC: Trafford.

Meltzer, G. (2010) Cohousing and Ecovillages. Paper presented to the International Collaborative Housing Conference, Stockholm.

Mulder, K., Costanza, R. and Erickson, J. (2006) The contribution of built, human, social and natural capital to quality of life in intentional and unintentional communities. Ecological Economics, 59, pp. 13-23.

Munasinghe M., Dasgupta, P., Southerton, D., Bows, A. and McMeekin A. (2009) Consumers, Business and Climate Change. Manchester: Sustainable Consumption Institute, University of Manchester.

Røpke, I. (1998) The dynamics of willingness to consume. Ecological Economics, 28, pp. 399-420.

Statistics Denmark (2011) FAM122N: Adults by Region, Type of Household, Number of Persons and Number of Children in the Household, Sex and Age. Copenhagen: Statistics Denmark. Available at: http://www.statistikbanken.dk/statbank5a/ default.asp? $\mathrm{w}=1600$. Accessed 20 February 2012.

Torres-Antonini, M. (2006) Cohousing: Design for Environmental Conservation, Personal Empowerment, and Social Justice. Paper present to the Art \& Design for Social Justice Symposium, Tallahassee, FL.

Widener, M.N. (2010) Cohousing: joining affordable, sustainable and collaboratively-governed, single family neighborhoods. Real Estate Law Journal, 39, pp. 113-131.

Williams, J. (2005) Designing neighbourhoods for social interaction: the case of co-housing. Journal of Urban Design, 10, pp. 195-227.

Williams, J. (2007) Innovative solutions for averting a potential resource crisis - the case of one-person households in England and Wales. Environment, Development and Sustainability, 9, pp. 325-354.

Williams, J. (2008) Predicting an American future for co-housing. Futures, 40, pp. 268-286.

Wilson, A. and Boehland, J. (2008) Small is beautiful. U.S. house size, resource use, and the environment. Journal of Industrial Ecology, 9, pp. 277-287. 